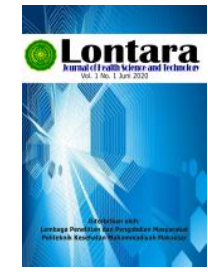

Lontara

Journal of Health Science and Technology

http://jurnal.poltekkesmu.online/lontarariset

Vol 1, No. 2, December 2020, pp 117-124

p-ISSN:0000-0000 dan e-ISSN: 2721-6179

DOI:https://doi.org/

\title{
Kemampuan Atraktan (Fermentasi Singkong dan Air Rendaman Udang Laut) pada Perangkap Nyamuk dalam Pengendalian Nyamuk
}

\author{
Yunicho, Baharuddin Sunu, Tahniar \\ Sanitasi, Politeknik Kesehatan Muhammadiyah Makassar \\ Email: yuniahmadkl07@gmail.com
}

\section{Artikel info}

\section{Artikel history:}

Received;03-10-2020

Revised:20-11-2020

Accepted;07-12-2020

\section{Keyword:}

Attractants, mosquito

traps, mosquito control.

\section{Kata Kunci:}

Atraktan, perangkap nyamuk, pengendalian nyamuk
Abstract. Mosquitoes are insects that act as vectors of disease. Some of the diseases caused by mosquitoes are Dengue Hemorrhagic Fever (DHF), filariasis, Malaria, Chikungunya and Encephalitis. Cases of mosquito-borne diseases are always increasing and can cause death. The purpose of this study was to determine the ability of attractant (fermented cassava and sea shrimp immersion) in mosquito traps in controlling mosquitoes. The research method used a quasi-experimental method. This research was conducted in Buhung Bundang Village, Bontotiro District, Bulukumba Regency. The results showed that the addition of attractants had the ability to attract mosquitoes to land on the traps. Of the two attractants used, fermented cassava was the most preferred attractant for mosquitoes compared to shrimp immersion attractant. The number of mosquitoes caught in all mosquito traps was 62. The number of mosquitoes in the cassava fermentation attractant was 36, while the shrimp immersion attractant was 26. The conclusion of this study shows that mosquito traps with the addition of attractants from fermented cassava and sea shrimp immersion can be used in mosquito control.

Abstrak. Nyamuk merupakan serangga yang berperan sebagai vector penyakit. Beberapa penyakit yang disebabkan oleh nyamuk yaitu Demam Berdarah Dengue (DBD), filariasis (kaki gajah), Malaria, Chikungunya dan Encephalitis. Jumlah kasus penyakit yang ditularkan oleh nyamuk selalu meningkat dan dapat menyebabkan kematian. Tujuan penelitian ini untuk mengetahui kemampuan jenis atraktan (Fermentasi singkong dan air rendaman udang laut) pada perangkap nyamuk dalam mengendalikan nyamuk. Metode penelitian menggunakan metode eksperimen semu. Penelitian ini dilaksanakan di Desa Buhung Bundang Kecamatan Bontotiro Kebupaten Bulukumba. Hasil Penelitian menunjukkan penambahan atraktan memiliki kemampuan untuk menarik nyamuk agar hinggap pada perangkap. Dari kedua atraktan yang digunakan, fermentasi singkong merupakan atraktan yang paling disukai nyamuk dibandingkan atraktan air rendaman udang. Jumlah nyamuk yang tertangkap pada semua mosquito trap sebanyak 62 ekor. Jumlah nyamuk pada atraktan fermentasi singkong sebanyak 36 
ekor, sedangkan pada atraktan air rendaman udang sebanyak 26 ekor. Kesimpulan penelitian ini menunjukkan perangkap nyamuk dengan penambahan atraktan dari fermentasi singkong dan air rendaman udang laut dapat digunakan dalam pengendalian nyamuk.

Coresponden author:

Email: yuniahmadk107@gmail.com

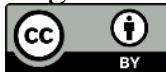

artikel dengan akses terbuka dibawah lisensi CC BY -4.0

\section{PENDAHULUAN}

Nyamuk merupakan serangga yang berperan sebagai vektor penyakit. Penyakit yang ditularkan nyamuk sangat merugikan bagi masyarakat perkotaan maupun pedesaan. Beberapa penyakit yang disebabkan oleh nyamuk yaitu Demam Berdarah Dengue (DBD), filariasis (kaki gajah), Malaria, Chikungunya dan Encephalitis. (Ningsih dkk, 2019)

Penyakit yang disebabkan oleh vektor nyamuk senantiasa meningkat dan menyebabkan kematian. Kasus demam berdarah misalnya dapat ditemukan di seluruh daerah tropis, dengan variasi spasial lokal dalam risiko sangat dipengaruhi oleh curah hujan, suhu dan tingkat urbanisasi. Dengan menggunakan pendekatan kartografi, diperkirakan ada 390 juta infeksi dengue per tahun, dimana 96 juta terlihat nyata. Jumlah infeksi ini lebih dari tiga kali perkiraan beban dengue dari Organisasi Kesehatan Dunia (WHO). (Bhatt et.al., 2013)

Di Indonesia jumlah kasus penyakit Demam Berdarah Dengue (DBD) di Indonesia hingga Juli 2020 dilaporkan mencapai 71.633. Selain itu jumlah kematian di seluruh Indonesia mencapai 459. Namun demikian jumlah kasus dan kematian tahun ini masih rendah jika dibandingkan tahun 2019. Tahun ini jumlah kasus DBD pada Januari - Juli mencapai 71.633 kasus, tahun 2019 jumlah kasus lebih tinggi berjumlah 112.954. Begitupun dengan jumlah kematian, tahun ini berjumlah 459, sedangkan tahun 2019 sebanyak 751. (Kemkes RI., 2020)

Solusi dalam pengendalian vektor nyamuk yang tujuannya adalah mengupayakan penurunan resiko penularan dengan meminimalkan habitat perkembangbiakan vector,mengurangi kontak antara dengan manusia serta memutus mata rantai penularan penyakit. Umumnya upaya menanggulangi gangguan nyamuk di masyarakat masih bergantung pada insektisida sintetik dan pengasapan (fogging). Biaya yang diperlukan dalam penggunaan insektisida ini sangat mahal namun efektivitas mematikan nyamuk dewasa hanya dalam jangka waktu pendek. (Fitriasih, 2008)

Dampak lain yang dapat ditimbulkan dari penggunaan insektisida yang berulang-ulang menimbulkan masalah baru yaitu membunuh serangga bukan target dan timbulnya resistensi vektor. Akibat dampak negatif yang ditimbulkan oleh insektisida kimiawi, telah merangsang para pakar untuk 
Kemampuan Atraktan (Fermentasi Singkong dan Air Rendaman Udang Laut) pada Perangkap Nyamuk dalam Pengendalian Nyamuk

(Yunicho, Baharuddin Sunu, Tahniar)

mencari alternatif pemberantasan vektor yaitu dengan cara pengendalian yang aman dan tidak menimbulkan masalah yang baru. (Fitriasih, 2008)

Pemanfaatan atraktan memiliki potensi dalam mengendalikan vektor nyamuk. Atraktan adalah sesuatu yang memiliki daya tarik terhadap serangga (nyamuk) baik secara kimiawi maupun visual (fisik). (Fitriasih, 2008). Penelitian Hsu Jia Chang (2007) mendesain alat perangkap nyamuk (Mosquito trap) yang terbuat dari botol air mineral bekas yang diisi dengan larutan gula dan ragi yang difermentasikan, dalam penelitiannya alat ini terbukti efektif dapat menangkap nyamuk. (Chu et.al, 2008) Sedangkan Penelitian Polson, et al (2002) menggunakan rendaman jerami sebagai atraktan pada ovitrap dan hal ini ternyata dapat mempengaruhi nyamuk Aedes dalam memilih tempat bertelur, hal ini terbukti dengan jumlah telur Aedes yang terperangkap. (A. Polson et.al, 2002)

Penggunaan atraktan dari beberapa studi memperlihatkan prospek yang cukup baik dalam memantau dan menurunkan kepadatan vektor DBD, penelitian Indra Dwinata, dkk, (2015) menyebutkan salah satu atraktan yang dapat menarik nyamuk untuk bertelur adalah atraktan air rendaman jerami. (Dwinata, 2015)

Atraktan dapat berasal dari kandungan tanaman yang mudah ditemukan di sekitar masyarakat atau bahan lain yang mempunyai aroma yang dapat menarik nyamuk untuk bertelur. Atraktan fermentasi singkong dan air rendaman udang memiliki aroma yang dapat menarik nyamuk untuk bertelur. Penelitian Eva Mai Saa'dah, dkk, (2018) menyebutkan larutan tape singkong berpotensi sebagai atraktan karena dapat menghasilkan CO2. (Sa'adah, dkk., 2018) Sedangkan hasil penelitian Sayono (2008) menunjukkan air rendaman udang memiliki senyawa kimia yang dikeluarkan dari proses biologi yang mampu tersebar dan tercium oleh nyamuk hingga 7-30 meter tergantung arah dan kecepatan angin .(Sayono, 2008)

Singkong dan air rendaman udang merupakan bahan yang mudah didapatkan oleh masyarakat berdasar pada penelitian sebelumnya untuk itu tujuan penelitian ini ingin membuktikan kemampuan atraktan dari fermentasi singkong dan air rendaman udang laut pada perangkap nyamuk sebagai upaya mengendalikan vektor penyakit yang disebabkan oleh nyamuk.

\section{METODE DAN BAHAN}

Jenis penelitian ini menggunakan eksperimen semu (Quasy Experimental). Penelitian dilaksanakan dalam dua tahapan. Pertama, tahap persiapan meliputi observasi pada lokasi penelitian dan pengumpulan data sekunder. Kedua, tahap pelaksanaan meliputi pembuatan perangkap nyamuk dengan jenis atraktan dari fermentasi singkong dan air rendaman udang laut serta air sumur sebagai control. Selanjutnya pemasangan perangkap di dalam dan di luar rumah sebanyak 10 rumah penduduk di desa Buhung Bundang Kabupaten Bulukumba. Jumlah nyamuk yang terperangkap dihitung kemudian data diolah dan disajikan dalam bentuk tabel.

Pembuatan perangkap nyamuk dengan menggunakan botol air mineral bekas ukuran 1.500 
liter kemudian dipotong 3/4 bagian. Pada potongan bagian atas botol direkatkan kembali dengan posisi mulut botol mengarah ke dalam dan dibungkus dengan kantong plastik berwarna hitam. Sebagai perlakuan digunakan kontrol yang berisi air sumur bor dan dua jenis atraktan yaitu fermentasi singkong dan air rendaman udang laut.

Pembuatan larutan fermentasi singkong dilakukan dengan cara memasukan singkong yang sudah dihaluskan atau diparut bersama ragi tape dengan perbandingan yaitu 1: 1 yaitu 1 bungkus ragi dan $1 \mathrm{~kg}$ singkong dalam $200 \mathrm{ml}$ air. Larutan didiamkan selama 2 jam dalam wadah tertutup agar proses fermentasi berlangsung. Selanjutnya larutan fermentasi singkong dimasukan ke dalam botol plastik dengan menggunakan corong.

Adapun pembuatan atraktan dari air rendaman udang laut yaitu dengan merendam kulit dan kepala udang. Perbandingan air rendaman air udang laut dengan kosentrasi $1: 2$ yaitu 1 kilogram udang laut dan 2 liter air dengan lama perendaman 30 menit. Kemudian dimasukkan ke dalam

perangkap nyamuk sebanyak $200 \mathrm{ml}$.

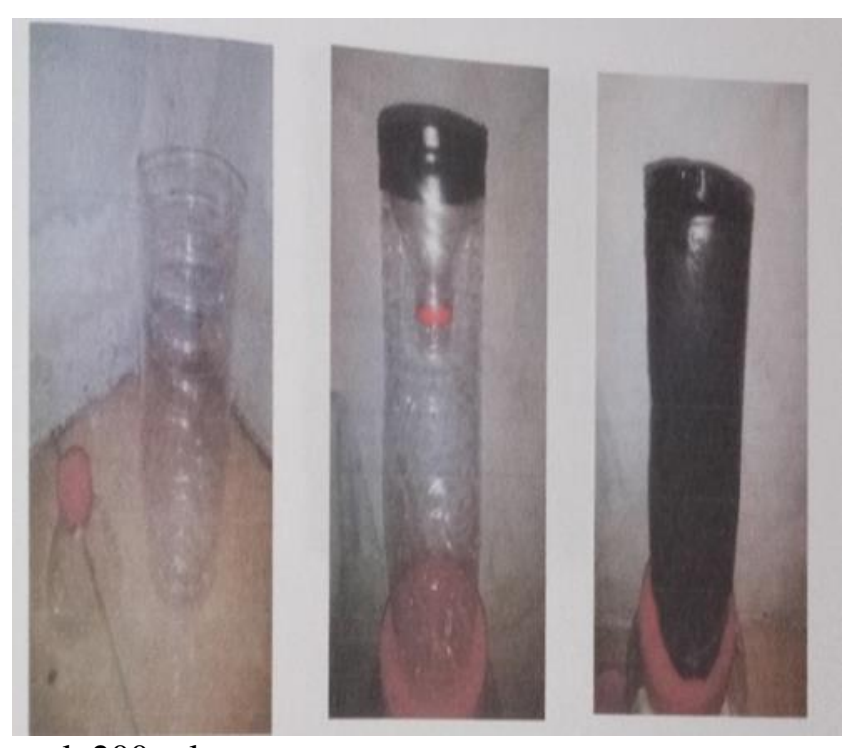

Gambar 1. Mosquito Trap

\section{HASIL DAN PEMBAHASAN}

\section{A. Hasil Penelitian}

Rata-rata nyamuk yang banyak terperangkap ditemukan pada perangkap nyamuk dengan atraktan fermentasi singkong pada hari ketiga sebanyak 15 ekor dan hari keempat sebanyak 12 ekor. Sedangkan pada hari keenam hingga kesepuluh jumlah nyamuk pada perangkap tidak ditemukan. Hal dapat dilhat pada tabel 1 berikut ini.

Tabel 1. Hasil Pengamatan Nyamuk yang Terperangkap Pada Mosquito Trap dengan Atraktan Fermentasi Singkong 
Kemampuan Atraktan (Fermentasi Singkong dan Air Rendaman Udang Laut) pada Perangkap Nyamuk dalam Pengendalian Nyamuk

(Yunicho, Baharuddin Sunu, Tahniar)

\begin{tabular}{|c|c|c|c|c|c|c|c|c|c|c|c|}
\hline \multirow{3}{*}{ Titik pengamatan } & \multicolumn{10}{|c|}{ Pengamatan nyamuk yang terperangkap } & \multirow{3}{*}{ Jumlah } \\
\hline & \multicolumn{10}{|c|}{ Hari } & \\
\hline & I & II & III & IV & $\mathrm{V}$ & VI & VII & VIII & IX & $\mathrm{X}$ & \\
\hline A & 0 & 0 & 2 & 1 & 1 & 0 & 0 & 0 & 0 & 0 & 4 \\
\hline $\mathrm{B}$ & 0 & 0 & 3 & 2 & 1 & 0 & 0 & 0 & 0 & 0 & 6 \\
\hline $\mathrm{C}$ & 0 & 1 & 1 & 1 & 0 & 0 & 0 & 0 & 0 & 0 & 3 \\
\hline $\mathrm{D}$ & 0 & 1 & 2 & 1 & 0 & 0 & 0 & 0 & 0 & 0 & 4 \\
\hline $\mathrm{E}$ & 0 & 0 & 1 & 2 & 1 & 0 & 0 & 0 & 0 & 0 & 4 \\
\hline $\mathrm{F}$ & 0 & 0 & 1 & 1 & 0 & 0 & 0 & 0 & 0 & 0 & 2 \\
\hline G & 0 & 0 & 1 & 1 & 1 & 0 & 0 & 0 & 0 & 0 & 3 \\
\hline $\mathrm{H}$ & 0 & 0 & 2 & 1 & 1 & 0 & 0 & 0 & 0 & 0 & 4 \\
\hline I & 0 & 0 & 1 & 1 & 1 & 0 & 0 & 0 & 0 & 0 & 3 \\
\hline $\mathrm{J}$ & 0 & 0 & 1 & 1 & 1 & 0 & 0 & 0 & 0 & 0 & 3 \\
\hline Jumlah & 0 & 2 & 15 & 12 & 7 & 0 & 0 & 0 & 0 & 0 & 36 \\
\hline
\end{tabular}

Sumber : Data Primer, 2020

Nyamuk yang terperangkap pada perangkap nyamuk tanpa atraktan hanya berisi air sumur tidak ditemukan. Hal dapat dilihat pada tabel 3 berikut ini.

Tabel 3. Hasil Pengamatan Nyamuk yang Terperangkap pada Mosquito Trap tanpa atraktan hanya air sumur

\begin{tabular}{|c|c|c|c|c|c|c|c|c|c|c|c|}
\hline \multirow{3}{*}{ Titik pengamatan } & \multicolumn{10}{|c|}{ Pengamatan nyamuk yang terperangkap } & \multirow{3}{*}{ Jumlah } \\
\hline & \multicolumn{10}{|c|}{ Hari } & \\
\hline & I & II & III & IV & $\mathrm{V}$ & VI & VII & VIII & IX & $\mathrm{X}$ & \\
\hline A & 0 & 0 & 0 & 0 & 0 & 0 & 0 & 0 & 0 & 0 & 0 \\
\hline $\mathrm{B}$ & 0 & 0 & 0 & 0 & 0 & 0 & 0 & 0 & 0 & 0 & 0 \\
\hline $\mathrm{C}$ & 0 & 0 & 0 & 0 & 0 & 0 & 0 & 0 & 0 & 0 & 0 \\
\hline $\mathrm{D}$ & 0 & 0 & 0 & 0 & 0 & 0 & 0 & 0 & 0 & 0 & 0 \\
\hline $\mathrm{E}$ & 0 & 0 & 0 & 0 & 0 & 0 & 0 & 0 & 0 & 0 & 0 \\
\hline $\mathrm{F}$ & 0 & 0 & 0 & 0 & 0 & 0 & 0 & 0 & 0 & 0 & 0 \\
\hline $\mathrm{G}$ & 0 & 0 & 0 & 0 & 0 & 0 & 0 & 0 & 0 & 0 & 0 \\
\hline $\mathrm{H}$ & 0 & 0 & 0 & 0 & 0 & 0 & 0 & 0 & 0 & 0 & 0 \\
\hline I & 0 & 0 & 0 & 0 & 0 & 0 & 0 & 0 & 0 & 0 & 0 \\
\hline $\mathrm{J}$ & 0 & 0 & 0 & 0 & 0 & 0 & 0 & 0 & 0 & 0 & 0 \\
\hline Jumlah & 0 & 0 & 0 & 0 & 0 & 0 & 0 & 0 & 0 & 0 & 0 \\
\hline
\end{tabular}

Sumber : Data Primer, 2020

Jumlah nyamuk yang terperangkap pada perangkap aktraktran dari fermentasi singkong lebih banyak dibanding jumlah nyamuk yang terperangkap pada atraktan air rendaman udang laut yaitu 36 ekor nyamuk dan 26 ekor nyamuk yang tertangkap pada air rendaman udang laut (tabel 1 dan tabel 2). Adapun air sumur sebagai control dalam penelitian ini tidak ditemukan keberadaan nyamuk yang terperangkap (tabel 3). Pengamatan dilakukan pada 10 rumah selama 10 hari.

Adapun pada atraktan air rendaman udang pada tabel 2 menunjukkan hasil yang tidak jauh berbeda dengan atraktan fermentasi singkong yakni pada hari kedua mulai ditemukan nyamuk yang terperangkap pada titik pengamatan 3 dan 4 , pada hari ke tiga semua titik pengamatan ditemukan nyamuk yang terperangkap baik dari fermentasi singkong maupun air rendaman udang laut.

Hal ini disebabkan karena aroma atraktan pada hari ke 3-4 merupakan aroma yang disukai nyamuk. Sedangkan pada hari ke enam hingga ke sepuluh nyamuk tidak ditemukan dikarenakan 
aroma fermentasi singkong mulai berkurang sehingga berpengaruh terhadap hasil nyamuk yang terperangkap.

\section{B. Pembahasan}

Penelitian ini menggunakan perangkap nyamuk dari botol mineral bekas dengan atraktan fermentasi singkong dan air rendaman udang. Banyaknya jumlah nyamuk ditemukan pada atraktan fermentasi singkong dibanding atraktan dari air rendaman udang laut dikarenakan aroma yang kuat dihasilkan oleh fermentasi singkong, hasil temuan dalam penelitian ini sejalan dengan penelitian Eva Mai Saa'dah, dkk. (2018) yang menyatakan bahwa larutan tape singkong berpotensi sebagai atraktan karena dapat menghasilkan CO2. (Sa'adah, dkk., 2018)

Pada penelitian ini, masing-masing perangkap nyamuk dengan atraktan air rendaman udang, fermentasi singkong dan air sumur bor sebagai kontrol dipasang pada 10 rumah penduduk di Desa Buhung bundang Kecamatan Bontotiro Kabupaten Bulukumba dengan cara meletakkan ketiga perangkap tersebut. Penelitian dilakukan selama 10 hari dan pengamatan dilakukan setiap hari pada pukul 10.00 WITA untuk mengetahui jumlah nyamuk yang tertangkap.

Penambahan atraktan air rendaman udang yang digunakan adalah udang laut atau udang yang banyak dijual di pasaran sehingga mudah didapat. Udang yang digunakan yakni sebanyak 1 kilogram (hamya cangkang dan kepala udang) dengan penambahan air sebanyak 2 liter direndam selama 30 menit kemudian dimasukkan $200 \mathrm{ml}$ ke dalam perangkap nyamuk yang telah didesain berupa botol air mineral bekas ukuran 1.500 liter kemudian dipotong 3/4 bagian lalu bagian atasnya dibalik ke bawah sehingga mulut botol ada di dalam botol kemudian diberi lakban lalu dibungkus dengan plastik berwarna hitam (gambar 1) dan kemudian diletakkan pada rumah penduduk.

Jumlah nyamuk yang tertangkap pada atraktan air rendaman udang dan fermentasi singkong serta air sumur bor sebagai kontrol menunjukkan perbedaan yang signifikan yakni pada atraktan fermentasi singkong didapatkan nyamuk yang tertangkap sebanyak 36 ekor (58\%) sedangkan atraktan air rendaman udang hanya 26 ekor $(42 \%)$ dan untuk air sumur bor sebagai kontrol tidak ada nyamuk yang tertangkap.

Berdasarkan hasil yang diperoleh pada penelitian diketahui bahwa perangkap nyamuk dengan penambahan atraktan memiliki pengaruh sebagai umpan untuk menarik nyamuk agar hinggap pada perangkap nyamuk dan penambahan atraktan fermentasi singkong memiliki potensi atau kemampuan lebih besar dibandingkan air rendaman udang.

Singkong memiliki kandungan karbohidrat yang cukup tinggi yaitu dalam 100 gram singkong mengandung 38 gram karbohidrat, oleh karena itu singkong merupakan salah satu bahan makanan yang sering digunakan untuk pembuatan tape yaitu melalui proses fermentasi dengan bantuan ragi. (Sa'adah, dkk., 2018)

Produk yang dihasilkan dari fermentasi singkong adalah tape dimana terjadi perombakan bahan-bahan yang tidak sederhana. Zat pati yang ada dalam bahan makanan diubah menjadi bentuk 
Kemampuan Atraktan (Fermentasi Singkong dan Air Rendaman Udang Laut) pada Perangkap Nyamuk dalam Pengendalian Nyamuk

(Yunicho, Baharuddin Sunu, Tahniar)

yang sederhana yaitu gula, dengan bantuan suatu mikroorganisme yang disebut ragi. (Sa'adah, dkk., 2018)

Adapun air rendaman udang mengandung sisa protein atau hasil metabolisme lain dan senyawa kimia baik dalam bentuk gas maupun cair yang disukai nyamuk. Rendaman air udang juga mengekskresi ammonia dan karbon dioksida. (Sayono, 2008)

Konsentrasi $\mathrm{CO}_{2}$ merupakan salah satu zat kimia yang dapat menarik nyamuk melalui organ penciuman nyamuk (olfactori) sehingga dapat digunakan sebagai atraktan. (Sayono, 2008). Hal ini sejalan dengan penelitian Santjaka (2013), yang menyatakan bahwa nyamuk tertarik pada $\mathrm{CO}_{2}$ yang dihasilkan manusia pada proses pernafasannya sehingga nyamuk akan ditemui berada dan menjadikan sekitar pemukiman manusia sebagai tempat perkembangbiakannya (Breeding site). (Santjaka, 2013)

Rata-rata nyamuk yang mulai terperangkap pada perangkap nyamuk baik dengan atraktan fermentasi singkong maupun atraktan air rendaman udang laut yakni pada hari kedua hingga hari ke lima. Hal ini disebabkan karena aroma atraktan pada hari ke dua hingga ke lima aroma yang disukai nyamuk. Sedangkan pada hari ke enam hingga hari ke sepuluh atraktan mulai beraroma tajam yang memungkinkan nyamuk tidak menyukai aroma tersebut sehingga berpengaruh terhadap hasil nyamuk yang terperangkap.

Adapun faktor lain yang ikut mempengaruhi sehingga atraktan tersebut tidak disukai nyamuk seperti keberadaan semut dan lalat yang mengerumuni parangkap tersebut sehingga tidak ada nyamuk yang mendekat atau terperangkap.

\section{KESIMPULAN DAN SARAN}

Perangkap nyamuk (mosquito trap) dengan penambahan atraktan memiliki pengaruh sebagai umpan untuk menarik nyamuk agar hinggap pada perangkap. Dari kedua atraktan yang digunakan, fermentasi singkong merupakan atraktan yang paling disukai nyamuk dibandingkan atraktan air rendaman udang laut dengan jumlah nyamuk yang tertangkap pada atraktan fermentasi singkong sebanyak 36 ekor sedangkan pada atraktan air rendaman udang hanya 26 ekor.

Adapun saran yang peneliti dapat ajukan yaitu penggunaan atraktan sebagai perangkap nyamuk dapat disosialisasikan kepada masyarakat sebagai upaya dalam pengendalian vektor nyamuk dan untuk penelitian selanjutnya untuk melihat kemampuan atraktan sebaiknya disertai pengukuran faktor-faktor lingkungan yang merupakan bionomik nyamuk sebagai vektor penyakit.

\section{UCAPAN TERIMA KASIH}

Terima kasih diucapkan kepada Direktur, dan seluruh civitas akademika prodi Sanitasi Politeknik Kesehatan Muhammadiyah Makassar yang telah membantu terlaksananya seluruh rangkaian penelitian ini. 


\section{DAFTAR PUSTAKA}

A Polson, K., Curtis, C., Moh Seng, C., G Olson, J., Chantha, N., \& C Rawlins, S. (2002). The use of ovitraps baited with hay infusion as a surveillance tool for Aedes aegypti mosquitoes in Cambodia.

Bhatt, S., Gething, P. W., Brady, O. J., Messina, J. P., Farlow, A. W., Moyes, C. L., ... \& Myers, M. F. (2013). The global distribution and burden of dengue. Nature, 496(7446), 504-507.

Chu, Y. L., \& Hsu, C. C. (2008). Mosquito Trap. U.S. Patent Application No. 11/777,330.

Dwinata, I., Baskoro, T., \& Indriani, C. (2015). Autocidal Ovitrap Atraktan Rendaman Jerami Sebagai Alternatif Pengendalian Vektor DBD di Kab. Gunungkidul. PERENNIAL, 11(2), 125-131.

Fitriasih, Retno Hestiningsih, Sayono. (2008). Pengaruh Jenis Atraktan Pada Alat Perangkap Nyamuk Model China Terhadap Jumlah Nyamuk Aedes Aegypti Yang Terperangkap. [online] http://digilib.unimus.ac.id/files//disk1/21/jtptunimus-gdl-s1-2008-fitriasiha-1028-1-abstrak.pdf

Kemenkes RI. (2020) Hingga Juli, Kasus DBD di Indonesia Capai 71 Ribu. [online] diakses dari https://www.kemkes.go.id/article/view/20070900004/hingga-juli-kasus-dbd-di-indonesiacapai-71-ribu.html

Ningsih, P. R., Nukmah, N., \& Soekardi, H. (2019). Pengaruh Dua Jenis Atraktan Sebagai Ovitrap Telur Nyamuk Pada Tiga Lokasi Berbeda. PROSIDING SN-SMIAP, 148.

Sa'adah, E. M., Isnawati, I., \& Noraida, N. (2018). Larutan Tape Singkong (Manihot utilissima) sebagai Atraktan Nyamuk. JURNAL KESEHATAN LINGKUNGAN: Jurnal dan Aplikasi Teknik Kesehatan Lingkungan, 15(1), 541-548.

Santjaka, A. (2013). Malaria pendekatan model kausalitas. Yogyakarta: Nuha Medika

Sayono, S. (2008). Pengaruh Modifikasi Ovitrap terhadap Jumlah Nyamuk Aedes yang Terperangkap (Doctoral dissertation, Program Pasca Sarjana Universitas Diponegoro). 